\title{
AN ANALYSIS OF DIRECTIVE SPEECH ACT FOUND IN "KOI MIL GAYA" MOVIE
}

\author{
Tira Nur Fitria \\ STIE AAS Surakarta \\ tiranurfitria@gmail.com
}

Submission
Track:
Received:
24-04-2019
Final Revision:
22-10-2019
Available online:
31-10-2019
Corresponding
Author:
Tira Nur Fitria
tiranurfitria@gmail.com

\begin{abstract}
The aim of this research is to find out the type of directive speech acts and to find out which directive speech acts most frequently used in "Koi Mil Gaya" movie. The research is conducted by using a qualitative approach. This research describes the phenomenon, the data, the situation, as it is really found. The technique of data collection in this research is a documentary study. From the result of this study, the writer finds that there are 246 utterances of directive speech act produced by the characters in the movie as 196 data. The form of the directive act can be found in utterances which contain words, phrase, clause, and sentences. From the analysis shows that in "Koi Mil Gaya" movie shows a directive speech act which contains three aspects, they are command, request, and suggestion. First, in command, there are 165 data (utterances) or $84.18 \%$. Second, in suggestion, there are 20 data/utterances or $10.20 \%$. Third, in a request there are 11 datal/utterances or $5.61 \%$. While the most dominant type of directive speech act is in command.
\end{abstract}

Keywords: Speech Act, Directive, Movie

\section{INTRODUCTION}

Pragmatic is part of a linguistic study. Pragmatics is about how the listener interprets utterances and the speaker produces interpretable utterances (Griffiths, 2006: 21). While Yule (2005:3) defines that pragmatics is the study of how more get communicated than what is said. 
Therefore, in daily communication, we usually use the utterances in acting, which is known as a speech act.

A speech act is a part of a pragmatic study that studies about utterances. Speech acts can shed a great deal of light on broader cultural themes, but equally the significance of any particular speech act category can only be fully understood in broader cultural context (Abdullah, 2012). Nastri et.al (2006) states that the function of speech act is a functional unit of language that informs people to do things with words, which means the speaker performs an act of saying something in order to participate in a communication.

According to Searle (1969), one can perform only five basic actions in speaking, by means of the following types of utterances, they are representative (committing the speaker to the truth of the expressed proposition), directives (making the hearer to do something), commissive (the speaker commits himself to a certain course of an action to be taken in the future), expressive (expressing the speaker's feelings, and declarative (bringing out a change in the external situation of the world through utterances.

Directives are used by the speaker who attempts to get the addressee to carry out an action. According to Austin (1962), directives are used by the speaker to get the hearers/listeners do or not to do something. It can be in the form of order, warning, urging, directing, and advising. As stated by Cutting (2002: 17), directives cover acts in which the words are aimed at making the hearers/listeners do something, such as commanding, requesting, inviting, advising and suggesting.

Schmidt and Richards (1980), as cited in Flor (2005), state that in directive contains speech acts such as request, command, and suggestion. Each type of directive has a different purpose and function. The main goal is to get the hearer to do something, although the force of the attempt can differ from one speech act to another. While, Amalsaleh et al. (2004) state that the same form of directives may imply the different functions or conversely, the same function also may be expressed via a variety of forms.

In short, the researcher chooses this topic based on the consideration of the fact that the directive is found here as a linguistic phenomenon. The writer wants to show several kinds of the directive is used in a movie. Directive speech acts often happens in daily life and communication which related to society or community members and language development especially in a movie. They are essential actions in social interactions. It is also can be found in the movie. When the characters in the movie ask the other characters to do something, it means that the characters (as a speaker) perform a speech act which is called as a directive.

There are many movies which contain the directive speech act. One of the examples is "Koi Mil Gaya" movie. "Koi Mil Gaya" (English: Found Someone) is a 2003 Indian science fiction film directed by Rakesh Roshan (who also has a cameo role). It is the first installment in Krrish (franchise). The film stars are Hrithik Roshan and Preity Zinta in the lead roles with Rekha plays an important supporting role.

There is a previous study that is related to the directive speech acts in a movie/film. Research is written by Kristiani and Muhartoyo (2013) entitled An Analysis of Directive Speech Acts in the Movie "Sleeping Beauty". This study aims to find out how often the directive speech acts performed and which type of directive speech acts that are most frequently used in the 
movie. The writer uses a qualitative method by collecting data from watching the movie, analyzing the body movement and the dialogues of each character, read the script and library research. A total of 139 directive speech acts were successfully identified. The result of the analysis shows that the directive speech acts of ordering are the most frequently used in the movie $(21,6 \%)$. The least frequently used directive speech acts is inviting directive speech acts $(0,7 \%)$. The study also reveals the importance of directive speech acts in keeping the flow of the storyline of the movie. This study expected to give some useful insights into understanding what directive speech acts are.

This research has some similarities and differences with the previous research. In similarities, both of the two pieces of research analyze the same topic of directive speech act and focus on the movie. While in the differences, both of two pieces of research have the different title of the movie. The other differences are in the amount of data analyzed and the result of the research which surely will be different. Therefore, the writer is interested in exploring the use of directive speech acts in the movie and wants to find the answers to the following problems in this study. The writer formulates the goals of the research are to find out the type directive speech acts appear in "Koi Mil Gaya" movie and to find out which directive speech acts most frequently used in the movie.

\section{RESEARCH METHOD}

The research uses using a qualitative approach. Creswell (2012) states that in qualitative research, a central phenomenon is the key concept, idea, or process studied. In qualitative descriptive, the description of needs presentations of the facts of everyday language. This research describes the phenomenon, the data, the situation, as it is really found.

The technique of data collection in this research is a documentary study. This writer uses a documentary study because the data is in the form of a document or written text. Denscombe (2007: 230) argues that documents can be obtained from the internet such as website pages, home pages, or email and they can be treated like online documents. In this study, the data are obtained by watching the "Koi Mil Gaya" movie and read the English subtitle of the movie. The writer finds that there are 196 utterances of directive speech act produced by the characters in the movie.

In collecting the data, the writer tries to understand each of the dialogues/utterances and find out the directive speech acts performed in this movie. The writer only takes the dialogues/utterances that contain directive speech acts in this movie. Likewise, the writer downloads the script from the internet and prints it. The writer marks the dialogue that contains directive speech acts and identifies what kind of directive speech acts are performed in the dialogue. 


\section{RESULTS \& DISCUSSION}

\section{Results}

From the findings of this research, it is found that the directive act also found in "Koi Mil Gaya" movie. In the dialogues between the characters in the movie, it shows the directive utterances. The form of the directive act can be found in words, phrase, clause, and sentences. Furthermore, there are three types of directive acts which exist in this movie, they are command, request, and suggestion. The descriptions are as follows:

\section{Command}

A command is more commonly known as imperative. A command is one of the types of the directive act found in "Koi Mil Gaya" movie. A command is used to give orders or exert authority toward someone or something. The usual function of a command/imperative sentence is to give a command or instruction. It tells us to do something. Command sentences are used when people are telling someone to do something or not to do something. Imperatives are divided into two groups, they are positive and negative imperatives. For example:

\section{A. Positive Form}

Positive command/imperative is to form a positive imperative we use the base form of the verb. The base form is the form in the dictionary. For example:

(1) Code : 001-KMG-M

Directive : Look! They're responding!

(2) Code : 049-KMG-M

Directive : Wait!

(3) Code : 026-KMG-M

Directive : Move...move!

(4) Code : 082-KMG-M

Directive : Sir! Look!

(5) Code : 156-KMG-M

Directive : Go... go home.

From the example, the number 1-5 above show that the utterances contain the directive speech act. We should also use commands when you are writing instructions telling someone how to do something. Commands usually start with an imperative verb, also it is known as a 'bossy verb' because they tell someone to do something. The typical form (structure) of an English imperative sentence uses the base verb with no subject. In fact, many imperative sentences consist of nothing but the verb. The final punctuation is usually found is ending a full-stop/period (.) or an exclamation mark/point (!).

(6) Code : 081-KMG-M

Directive : Please... give me some strength, Lord!

(7) Code : 149-KMG-M

Directive : Lord Krishna, please do something.

(8) Code : 190-KMG-M

Directive : Please, I request 
From the example, number 6-8 above show that the utterances contain the directive speech act. Although we use imperative sentences to give direct commands, we can also use them to give instructions more politely than a straight command. Imperatives can also be used with words like "please" or "kindly" to add politeness.

(9) Code : 028-KMG-M

$\begin{array}{lll}\text { (10) } \text { Code } & : & \text { Sukhwani, give } \\ & \text { : } 44-K M G-M\end{array}$

Directive : Give me more.

(11) Code : 046-KMG-M

Directive : Give us some food.

(12) Code : 059-KMG-M

Directive : Go and take your seat.

(13) Code : 068-KMG-M

Directive : Give her a nice present.

From the example, number 9-13 above show that the utterances contain the directive speech act. Imperative with a pronoun. Normally when we use the imperative there is no subject because the subject is obvious-it's YOU! Sometimes, however, to make the subject clear, we do use an object pronoun. For example, "them, me, us, your and her".

(14) Code : 071-KMG-M

Directive : Sit down, son.

(15) Code : 074-KMG-M

Directive : Nisha, save the page.

(16) Code : 078-KMG-M

Directive : Rohit, come quickly.

(17) Code : 123-KMG-M

Directive : Rohit, pass the ball.

(18) Code : 175-KMG-M

Directive : See, auntie? Rohit said he'd make it big someday.

From the example, number 14-18 above show that the utterances contain the directive speech act. Imperative with a pronoun. Normally when we use the imperative there is no subject because the subject is obvious-it's YOU! Sometimes, however, to make the subject clear, we do use a subject pronoun, for example, the name stated above.

(19) Code : 031-KMG-M

Directive : Hope you've got the message. 
From the example, number 19 above show that the utterances contain the directive speech act. From the example above shows that "hope" is placed at the beginning of the sentences. We often express hope and make suggestions with the imperative form, but these are not real commands.

(20) Code : 037-KMG-M

Directive : Let's go. We'll take you there.

(21) Code : 066-KMG-M

Directive : Then, let's dance together.

(22) Code : 075-KMG-M

Directive : So, let's go to my house! I have my Papa's computer.

Code : 145-KMG-M

Directive : Really? So let's have a match.

Code : 157-KMG-M

Directive : Let's hide him in my house. My parents are away.

From the example, number 19 above show that the utterances contain directive speech act. The Imperative with let's. Let's with an apostrophe is a contraction of "let us," which is used in all varieties of speech and writing to introduce a suggestion or request.

\section{B. Negative Form}

Negative command/imperative is to form a negative imperative. Sometimes we want to tell someone not to do something. In this case, we simply add the word Don't or Do not before the verb to make a negative sentence in English, for example:

(25) Code : 008-KMG-M

Directive : You want to be the Eiffel Tower?. Don't insult our friend.

(26) Code : 057-KMG-M

Directive : Don't hit me! I'm telling you the truth.

(27) Code : 103-KMG-M

Directive : Don't come out. We'll be back in a moment, okay?

Code : 134-KMG-M

Directive : Don't scream, Ma! Someone might come here

Code : 147-KMG-M

Directive : Don't move, okay?

From the example, number 25-29 above show that the utterances contain the directive speech act of negative imperatives. The negative form is do + not + base verb. Do + Not (Don't) + Main Verb (Infinitive) + Object or Complement.

(30) Code : 005

Directive : Don't be disheartened.

(31) Code : 132

Directive : No, Ma. Don't be afraid! This is Jadoo, he's a friend 
From the example, number 25-29 above show that the utterances contain of the directive speech act negative imperatives. The formula is $B e+$ Adjective.

\section{Request}

A request is one of the types of directive acts found in "Koi Mil Gaya" movie. The request is the act of asking for something to be given or done, especially as a favor or courtesy; solicitation or petition. Here, the speaker attempts by the speaker to get the address to do something. Moreover, a request is an expression of what the speaker wants the addressee to do or refrain from doing. For example:

(1) Code : 036-KMG-M

Directive : I've just arrived in the city. Can you tell me where Shanti Villa is?

(2) Code : 108-KMG-M

Directive : Can't I see you and Rohit are having an affair?

(3) Code : 189-KMG-M

Directive : "Can you tell me how we will fly so high, without any wings?"

(4) Code : 195-KMG-M

Directive : Couldn't you even come to receive me?

From the example, number 1-4 above shows the directive act of request. Here, the speaker attempts by the speaker to get the address to do something. The modal 'can' be a commonly used modal verb in English. It is used to express; ability, opportunity, a request, to grant permission, to show possibility or impossibility. When we make requests, we can use can. In such sentences, can and could be used to make requests. The sentence is structured as a question so as to indicate that you are leaving it at the other person to decide if he wants to help you. We often use can or could to ask people to do things. Can and could also be used to express the continuous aspect of verbs of perception (see, hear, feel, taste, smell, etc.) and verbs like understand, remember, etc.

(5) Code : 182-KMG-M

Directive : Will you have something to drink, Rohit? Tea, coffee...?

(6) Code : 183-KMG-M

Directive : Will you teach me?

(7) Code : 184-KMG-M

Directive : "come closer, will you?"

(8) Code : 186-KMG-M

Directive : Will you really teach me?

(9) Code : 187-KMG-M

Directive : Will you go with us?

(10 Code : 188-KMG-M 
Directive : Will you be my friend?

From the example number 5-10 above shows the directive act of request. We can use "will" to talk about the future. "Will" is the auxiliary verb in the future simple tense, but can also be used when requesting someone to do something. It is important to bear in mind that "will" is a more casual way of making the request than using the conditional. We also use will to make requests. We often create interrogative sentences using will to make requests or polite offers.

(11) Code : 027

Directive : May I ask, where you gentlemen were going to, in such a hurry?

From the example number 11 above shows directive act of request. "May" is a modal verb. It can also be used to give or request permission, although this usage is becoming less common. In making requests require the speaker to be aware of levels of formality, so it becomes more formal. When making a request using may, only $I$ can be the subject. If you are making a formal request to ask someone, we would say "May, I ask...?".

\section{Suggestion}

A suggestion is one of the types of directive acts found in "Koi Mil Gaya" movie. The suggestion is the speaker's attitude and intentions when performing an utterance must be taken as a reason for the hearer's action. For example:

(1) Code : 022-KMG-M

Directive : You ought to be the first hand to rise in the class next time.

(2) Code : 039-KMG-M

Directive : You ought to be ashamed! You fool people along with these kids?

(3) Code : 055-KMG-M

Directive : We ought to hand him over to the police!

(4) Code : 121-KMG-M

Directive : You ought to inspire them to move ahead in life.

From the example number 1-4 above shows the directive act of suggestion. The verb ought to only exist in the simple present. Ought is unlike most other modals because we always use the infinitive to when we use it with the main verb. We use the modal ought to give our opinion of the best thing to do in a particular situation. Ought to basically mean the same thing as should, although should is more often used for advice, while ought to be used for moral obligations. Modal verbs 'should' and 'ought to' are used to give suggestions, advice, and recommendations.

(5) Code : 017-KMG-M

Directive : He shouldn't be in this school in the first place.

(6) Code : 040-KMG-M 
(7) Code : 056-KMG-M

Directive : Raj, why're allowing him to leave? He should be taught a lesson.

From the example number 6-7 above shows the directive act of suggestion. We use should and shouldn't give advice or to talk about what we think is right or wrong. Should is a modal verb. It is used to make recommendations or give advice. It can also be used to express obligation as well as expected. When we use should in a sentence, it gives the meaning of "It is a good idea".

Should usually be used to give advice, a recommendation or a suggestion. This is to say that it is the right thing to do or the correct thing. This example also includes something called "phrasal modals" - phrases such as has to, ought to. You can use any subject, place "should" after the subject, but before the base verb. The formula is Subject + Should + Base Verb. We can change the subjects in the sentences and you will see that when we use should, the verb remains in the base form.

Should not or shouldn't, just puts the sentence in the negative form. We use shouldn't advise doing something, usually because it is bad or wrong to do. Then, we are not recommending something, not advising something, not expecting something or "It's not a good idea." Should also be written in passive. The formula is Modal + Be + Past Participle. It indicates that something must/can/should be done by someone at sometimes.

\section{Discussion}

Directive act related to the speaker's communicative intention in producing the utterances. The speaker normally expects that his/her communicative intention will be recognized by the hearers. Both speaker and hearer usually help this process by the circumstances surrounding the utterances. Mey (2001: 120) states that the directive speech act is an effort of the speaker to direct some goals of the hearer's action. It means that the speaker has some goals by getting the hearer to do something. The directive act has a function to express what the speaker wants. It means that both of the speakers and the hearers need to understand about the directive speech act in order to create clear and good communication. It indicates that the core of directive speech acts is to get someone else to act something like the effect of the speaker's utterances.

Based on Kreidler (1998: 190-191) there are three kinds of directive utterances can be recognized: commands, requests, and suggestions. A command is effective only if the speaker has some degree of control over the actions of the addressee. A request is an expression of what the speaker wants the addressee to do or refrain from doing. A request does not assume the speaker. A suggestion is the utterances which we make to other persons to give our opinions as to what they should or should not do. 
Besides that, the Directive act is also can be found in the movie, for example in "Koi Mil Gaya" movie. In the conversation between the characters, it can be found the directive utterances as 196 data. The form of the directive act can be found in utterances which contain words, phrase, clause, and sentences. Furthermore, there are three types of directive acts which exist in this movie, they are command, request, and suggestion. Below the table frequency of directive speech in "Koi Mil Gaya" movie.

Table 1. Frequency Type of Directive Speech Act

\begin{tabular}{cccc} 
& \multicolumn{3}{c}{ DIRECTIVE SPEECH ACT } \\
\cline { 2 - 4 } & Command & Suggestion & Request \\
\hline TOTAL & 165 & 20 & 11 \\
\hline$\%$ & $\mathbf{8 4 . 1 8}$ & 10.20 & 5.61
\end{tabular}

From the table above, it shows that in "Koi Mil Gaya" movie shows a directive speech act which contains three aspects, they are command, request, and suggestion. First, in command, there are 165 data (utterances) or $84.18 \%$. Second, in suggestion, there are 20 data/utterances or $10.20 \%$. Third, in a request, there are 11 data//utterances or $5.61 \%$. While the most dominant type of directive speech act.

First, in command. The command is defined as to give orders or exert authority over someone or something. From the example above shows the directive act of command. Here, the speaker expects the hearer to do what he wants about. Then, it has to the hearer, he must do it. In this case, the hearer expresses the speaker's intentions.

Second, in suggestion. Here, the speaker gets the hearer to do something, in suggestion, and the speaker asks the hearer to take some action which the hearer believes that it will give benefit for her/himself. In making a suggestion, the hearer can follow or not what is the speaker to suggest about. It depends on believing and benefit of the hearer.

Third, in the request. The request is the act of asking for something to be given or done, especially as a favor or courtesy; solicitation or petition. Moreover, the request is an expression of what the speaker wants the addressee to do or refrain from doing.

\section{CONCLUSION}

In "Koi Mil Gaya" movie shows the directive act. The form of the directive act can be found in utterances which contain words, phrase, clause, and sentences. Furthermore, there are three types of directive acts which exist in this movie, they are command, request, and suggestion. Below the table frequency of directive speech in "Koi Mil Gaya" movie. In the conversation between the characters, it can be found the directive utterances as 196 data. The form of the directive act can be found in utterances which contain words, phrase, clause, and sentences. Furthermore, there are three types of directive acts which exist in this movie, they are command, request, and suggestion. Below the table frequency of directive speech in "Koi Mil Gaya" movie. 
From the analysis shows that in "Koi Mil Gaya" movie shows a directive speech act which contains three aspects, they are command, request, and suggestion. First, in command, there are 165 data (utterances) or $84.18 \%$. Second, in suggestion, there are 20 data/utterances or $10.20 \%$. Third, in a request, there are 11 data//utterances or $5.61 \%$. While the most dominant type of directive speech act.

\section{REFERENCES}

Abdullah, Esbah Shaker \& Thomas Voon Foo. 2012. Offering as a Commissive and Directive Speech Act: Consequence for Cross-Cultural Communication. International Journal of Scientific and Research Publications, Volume 2, Issue 2, March 2012.

Amalsaleh, E., Yamini, H. \& Yarmohammadi, Y. (2004). Directives Used in University Classrooms. Journal of Literature and Language 5 (1) p. 1-27. Retrieved January 14, 2019 from www.ensani.ir/storage/Files/20120506 112631-5138-96.pdf

Creswell, J.W (2012). Educational Research (4th ed.). Boston: Pearson Education

Cutting, Joan. (2002). Pragmatic and Discourse. New York: Routledge.

Denscombe, M. (2007). The Good Research Guide: for Small-Scale Social Research Projects. New York: Open University Press.

Flor, A, M. (2003). Non-native Speakers Production of Advice Acts: The Effect of Proficiency. RESLA. 16: 139-153.

Griffiths, Patrick. (2006). An Introduction to English Semantics and Pragmatics. Edinburgh University Press Ltd

Kristiani \& Muhartoyo (2013). An Analysis of Directive Speech Acts in the Movie "Sleeping Beauty”. Unpublished Thesis. Jakarta: Binus University

Kreidler, C. W. (1998). Introducing English Semantics. London: Routledge.

Mey, J. (2001). Pragmatics. Oxford: Blackwell Publishing.

Nastri, J., Peña, J., \& Hancock, J. T. (2006). The Construction of Away Messages: A Speech Act Analysis. Journal of Computer-Mediated Communication

Yule, George. (2005). Pragmatics. New York: Oxford University Press. 